
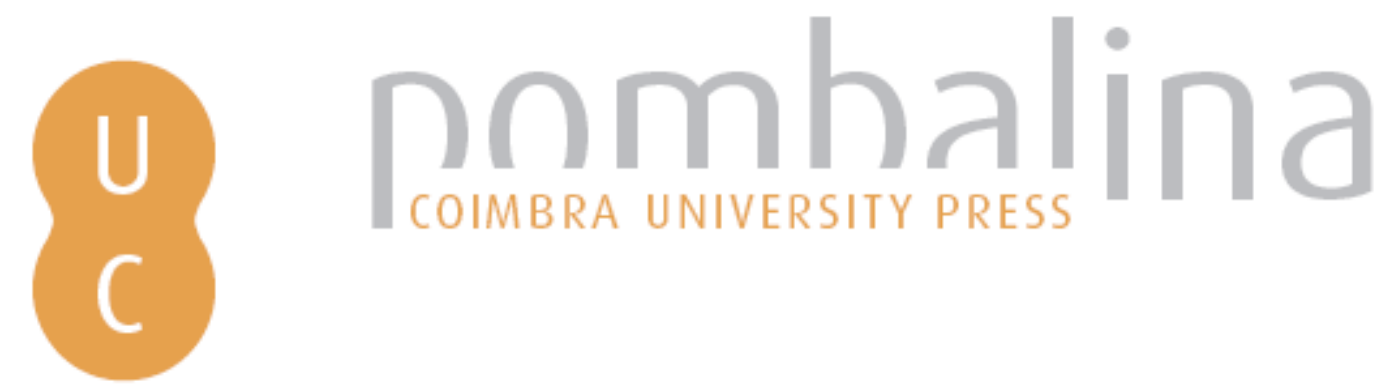

\title{
Does prescribed burning reduce the amount of inflorescences in conifer forests?: implications for management in pure and mixed Pinus nigra stands
}

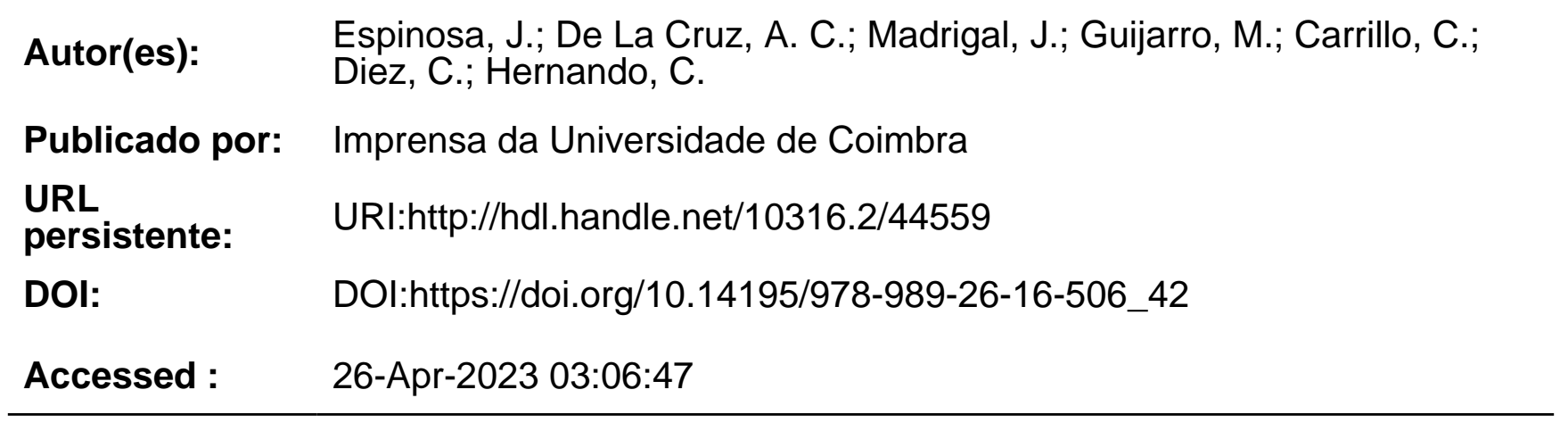

A navegação consulta e descarregamento dos títulos inseridos nas Bibliotecas Digitais UC Digitalis, UC Pombalina e UC Impactum, pressupõem a aceitação plena e sem reservas dos Termos e Condições de Uso destas Bibliotecas Digitais, disponíveis em https://digitalis.uc.pt/pt-pt/termos.

Conforme exposto nos referidos Termos e Condições de Uso, o descarregamento de títulos de acesso restrito requer uma licença válida de autorização devendo o utilizador aceder ao(s) documento(s) a partir de um endereço de IP da instituição detentora da supramencionada licença.

Ao utilizador é apenas permitido o descarregamento para uso pessoal, pelo que o emprego do(s) título(s) descarregado(s) para outro fim, designadamente comercial, carece de autorização do respetivo autor ou editor da obra.

Na medida em que todas as obras da UC Digitalis se encontram protegidas pelo Código do Direito de Autor e Direitos Conexos e demais legislação aplicável, toda a cópia, parcial ou total, deste documento, nos casos em que é legalmente admitida, deverá conter ou fazer-se acompanhar por este aviso.

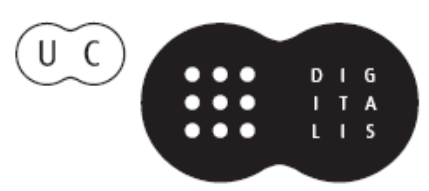




\section{ADVANCES IN}

\section{FOREST FIRE RESEARCH}

\section{8}

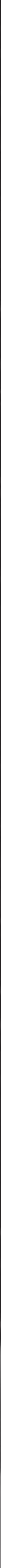




\title{
Does prescribed burning reduce the amount of inflorescences in conifer forests? Implications for management in pure and mixed Pinus nigra stands
}

\author{
J. Espinosa ${ }^{1 *}$; A.C. De La Cruz ${ }^{1}$; J. Madrigal ${ }^{1,2} ;$ M. Guijarro ${ }^{1,2} ;$ C. Carrillo ${ }^{1}$; C. Diez ${ }^{1}$; . \\ Hernando ${ }^{1,2}$ \\ ${ }^{1}$ INIA, Forest Research Centre, Department of Silviculture and Forest Management, Forest Fire \\ Laboratory. Ctra. Coruña Km 7,5 28040 Madrid, Spain. \{espinosa.juncal@inia.es*\} \\ ${ }^{2}$ iuFOR, University Institute for Sustainable Forest Management, uVA-INIA.
}

\begin{abstract}
Predictions of climate change project a future with an increasing incidence of fires. Prescribed burning, as a valuable tool for silvicultural management, might successfully reduce the severity and the intensity of subsequent wildfires, although with different effects on the individual tree. This is the reason why short term effect of prescribed burning in litterfall biomass is being evaluated in a network of experimental plots (18 plots of $50 \mathrm{~m} \times 50 \mathrm{~m}$ ) in pure (Pinus nigra Arn. ssp. salzmannii) and mixed (Pinus nigra $89 \%$ and Pinus pinaster Ait. 11\%) stands in two sites (El Pozuelo and Beteta) of Cuenca Mountains. An experimental design with 3 treatments (with 3 replicates) per site were performed (spring and autumn burning and control) and 8 litterfall collectors per plot were installed after burning.

Immediately after burning it was shown a short-term effect of prescribed burning in Beteta with an increase in amount of total litterfall in burned plots regarding unburned plots, although this effect was not significant in El Pozuelo there was an increase in needles. The increasing of total biomass (especially the amount of needles) could be an important effect determining the longevity of prescribed burning, especially in more productive ecosystems. Although, during the second year, the mean litterfall in burned plots is still higher than in control plots in Beteta, the differences have been reduced and the effect of fire has been weakened. The differences in the findings obtained between El Pozuelo and Beteta might be because of differences in pure and mixed stand structure.

Spanish black pine (Pinus nigra) is a not serotonin species, and the persistence of the ecosystem is related to the productions of inflorescences and the later establishment. Some studies reported that prescribed burning reduces de emergence and increase the mortality of seedling during the first year. In addition, Pinus nigra presents regular cycles of fructification every 6-8 years which generate discontinuous pulses of natural regeneration. Prescribed burning two years before a pulse of fructification (maturation period of cones) could be critical to guarantee the regeneration. In fact, during the first and second year, and in the two zones, it was detected a decrease in the amount of inflorescences in the burned plots regarding unburned plots.

In view of our findings prescribed burnings must be carefully planned in forest management, in particular when are aimed at regeneration in Pinus nigra pure and mixed stands, to avoid a negative impact of fire on the canopy. The possible dampening effect of the mixed stand is being evaluated too. The litterfall continues being monitored in and a complete database of litterfall in pure and mixed stands is being generated. Scarce information of the impact of fire in foliar and non-foliar biomass is available in Europe and more research is needed to confirm these preliminary results.
\end{abstract}

Keywords: litterfall, prescribed burning, Cuenca Mountains, defoliation, fire severity

\section{Introduction}

Fuels treatments reduce the quantity and continuity of fuels (vertical and horizontal) to mitigate fire severity (Graham et al., 2004). The effectiveness of treatments may vary depending on type, amount, size, spatial distribution and intensity of treatments, time since implementation, ecosystem type, topography, geographic location and weather conditions at the time of fire (Cochrane et al., 2012). 
Prescribed burning is a kind of treatment that removes surface fuels, kills small trees and shrubs, and scorches lower limbs (Finney, 2005). Hence, burning under controlled conditions allows reduce temporarily potential fire intensity (Fernandes and Botelho, 2003; Agee and Skinner, 2005) and reduces the severity of wildfire (Wimberly et al., 2009; Arkle et al., 2012). However, their effects (in both the short and long terms) on the vegetation are complexes and they vary affecting different parts of the individual tree (roots, bark, stem, crown, etc). In this study, special attention is given to the effect of the prescribed burning on crown trees. For this reason, monthly monitoring of litterfall has been carried out in unburned and burned plots. This information may be important in management decisions to determinate time between prescribed burnings. Furthermore, the negative impact of fire on forests is expected to increase in the future since model predictions indicate increased frequency, intensity and severity of forest fires due to land-use change and climate change (Flannigan et al., 2009).

For the purpose of this study pure stands of Pinus nigra (Spanish black pine) and mixed stands of Pinus nigra and Pinus pinaster (maritime pine) have been chosen. Spanish black pine is resistant to low intensity surface fires due to the thick bark characteristic of the species (Fulé et al., 2008; Touchan et al., 2012; Pausas, 2015). However, recurrent large wildfires and total lack of capacity of this nonserotinous pine to regenerate after fire (Espelta et al., 2003; Ordoñez et al., 2005; Fernandes et al., 2008; Lucas-Borja et al., 2017; Christopoulou et al., 2013) threatening the permanence of P. nigra forests in some Mediterranean areas. In addition, the species releases its seeds early in the year, at the beginning of spring, and therefore no seed bank is maintained after summer wildfires (Ordoñez et al., 2005). In Spain, the total area occupied by maritime pine that was burned between 1974 and 2010 was 674055 ha, representing $31 \%$ of the total burned forest area. Provenance of maritime pine of Cuenca Mountains does not produce serotinous cones (Alía et al. 1996) but has a thick bark that may allow trees survival after low intensity fires. Therefore, it is important to determine the level of impact of prescribed burnings in the production of inflorescences with the aim of guaranteeing the persistence of stands. In addition, several authors have reported higher stability of mixed species stands than of monocultures (e.g. Schütz et al., 2006; Felton et al., 2010). In fact, species composition is an important consideration for managers wanting to develop resilient stand with prescribed burning.

This study is a first attempt to compare litterfall patterns in pure stands of P.nigra and mixed stands of P.nigra and P. pinaster after execution of prescribed burning to prevent forest fires. Although in this paper only the effect of spring burning will be analyzed, the study is part of a more comprehensive research study on the impacts of prescribed burning (soil, vegetation, tree heating of trunks and growing) conducted under tree canopies, in two different seasons (spring and autumn).

\section{Material and methods}

\subsection{Study site}

Two sites in the Cuenca Mountains, El Pozuelo (40 33' 36" N / $\left.002^{\circ} 15^{\prime} 56^{\prime \prime} \mathrm{W}\right)$ and Beteta (40 $33^{\prime}$ $\left.06^{\prime \prime} \mathrm{N} / 002^{\circ} 06^{\prime} 32^{\prime \prime} \mathrm{W}\right)$, were chosen for the study. Both areas have slopes between 3 and $10 \%$ and altitude between 1015 and $1294 \mathrm{~m}$ a.s.l. The climate in the area is humid Mediterranean (Allué, 1990), with mean annual temperature of $10.7^{\circ} \mathrm{C}$ and an average precipitation in summer months (maximum litterfall season) of $56 \mathrm{~mm}$. The soil is calcareous (Lucas-Borja et. al., 2017). The mean shrub cover in both zones is in a range of 5-20\% and pine regenerated has irregular distribution. El Pozuelo has a mean density of 627 trees ha $^{-1}$ (mixed stand of Pinus nigra and Pinus pinaster) and an average height of $12.2 \mathrm{~m}$ with the first living branch appearing at $6.4 \mathrm{~m}$. The mean breast diameter is $19.8 \mathrm{~cm}$. The basal area is $25.4 \mathrm{~m}^{2} \mathrm{ha}^{-1}$. Beteta has a mean density of 1286 trees ha ${ }^{-1}$ (pure stand of Pinus nigra) and an average height of $13.2 \mathrm{~m}$, with the first living branch appearing at $8.2 \mathrm{~m}$. The mean breast diameter is $18.8 \mathrm{~cm}$. The basal area is $36.6 \mathrm{~m}^{2} \mathrm{ha}^{-1}$. 


\subsection{Experimental design}

As mentioned, the study is part of a wider study being carried out in El Pozuelo and Beteta. A network of experimental plots (12 plots: $\mathrm{n}=6$ in El Pozuelo and $\mathrm{n}=6$ in Beteta) of $50 \mathrm{~m} \times 50 \mathrm{~m}$ were established. Two treatments (spring burning and control) with a three replicates per treatment were applied. Subplots of $30 \mathrm{~m}$ x $30 \mathrm{~m}$ were established in the centre of each plot to avoid the edge effect. Data collection is being carried out in subplots. The plots are fairly homogeneous in terms of vegetation, density, orientation, etc. Plots $\mathrm{P} 2 \mathrm{C}, \mathrm{P} 5 \mathrm{C}, \mathrm{P} 9 \mathrm{C}$ represent the control plots and plots $\mathrm{P} 3 \mathrm{~B}$, P4B, P6B represent the burned plots in El Pozuelo. Plots B1C, B3C, B9C represent the control plots and $\mathrm{B} 2 \mathrm{~B}, \mathrm{~B} 5 \mathrm{~B}, \mathrm{~B} 6 \mathrm{~B}$ represent the burned plots in Beteta.

All the trees in each of the 12 plots were identified, and the following measurements were made: total height, height to the first live branch, diameter at heights of $0.3,0.6$ and $1.3 \mathrm{~m}$ from the base and maximum and minimum bark thickness at $0.6 \mathrm{~m}$ from the base

\subsection{Burning}

Prescribed burnings were carried out taking into account the usual season in the region (spring burning were carried out in May 2016). The strip ignition technique was applied at distances of 1-2 m, at downhill and with a head wind. During burnings, precipitation (Ortrat, S.L.; KW 3-02), wind speed (Casella; 178031C-3), temperature and relative humidity (Geonica; STH-5031) were recorded every 10 minutes at a meteorological station. The temperatures of the cambial (inner bark) and bark region (outer bark) of 15 randomly selected trees were monitored at a height of $0.6 \mathrm{~m}$ (height of maximum heating according to prescription) with type $\mathrm{K} 1 \mathrm{~mm}$ diameter inconel-sheathed thermocouples $(0.3 \mathrm{~s}$ of response time). The thermocouples were connected to data loggers (DT-USB TCDirect ${ }^{\circledR}$ ), which recorded the data with a frequency of 1 second. Maximum and minimum stem char height, percentage of crown scorch and scorch height were measured after burning.

The characteristics of prescribed burning in each plot are shown in Table 1 . The flame convection (chimney effect) generated a moderate mean maximum stem char height $(70 \mathrm{~cm}$ in El Pozuelo and 160 $\mathrm{cm}$ in Beteta). Thermocouples connected in inner bark recorded a mean temperature of $50{ }^{\circ} \mathrm{C}$ in $\mathrm{El}$ Pozuelo and $41^{\circ} \mathrm{C}$ in Beteta. Temperature was higher $60^{\circ} \mathrm{C}$ during $27.7 \mathrm{~s}$ in El Pozuelo and $27.9 \mathrm{~s}$ in Beteta. It is commonly accepted that cambial temperatures above $60{ }^{\circ} \mathrm{C}$ may cause necrosis of the cambium. In outer bark, the mean temperature in El Pozuelo was $209^{\circ} \mathrm{C}$ and $279^{\circ} \mathrm{C}$ in Beteta.

\subsection{Litterfall}

The litterfall collection system was designed in accordance with the recommendations outlined in the Manual of the United Nations Economic Commission for Europe under the project entitled "International Co-operative Program on Assessment and Monitoring of Air Pollution Effects on Forests " (ICP Forests) (Ukonmaanaho et al., 2016), to guarantee the quality and quantity of the sample.

After prescribed burnings a total of 8 litterfall collectors per plot were at regular intervals installed in both study sites. The catchment area $\left(0.38 \mathrm{~m}^{2}\right)$ of collectors is horizontal to correct the effect of slope. The bag is $0.75 \mathrm{~m}$ deep to prevent the sample from being lost as a result of wind action. The collectors were placed at a height of $1.2 \mathrm{~m}$ from the ground to enable adequate drainage by gravity and to prevent capture of biomass from shrub strata. They were anchored firmly to the ground to provide greater resistance to the inclement conditions or other types of disturbance. Fiberglass mesh (pore size $2 \mathrm{~mm}$ ) provides resistance against external weather conditions and also ensures drainage while preventing loss of smaller elements, such as needles. The material was collected monthly to prevent decomposition of the biomass or the chemical leachate. This frequency of collection also ensures the easy identification of the fine elements which are rapidly compressed. Samples were taken to the laboratory on the same day and oven-dried at $65^{\circ} \mathrm{C}$ to constant weight (i.e. for at least 48 hours). The samples from each plot were then combined and the main fractions separated (needles, cones, 
inflorescences, miscellaneous, branches of diameter $<2 \mathrm{~cm}$ and bark) other fractions are also separated (but the biomass are not significant for this study). For the purpose of this paper, special attention is being put into the results obtained in the collected inflorescences after spring burnings.

\subsection{Statistical analysis}

The data were tested for normality and when necessary were transformed (logarithmic and angular transformation). The General Linear Model (GLM) repeated measures procedure was used to perform an impact analysis of burning and control treatments, to identify the effect of prescribed burning on the above parameters. The between-subjects factor (treatment) included two levels (control and burning) and the within-subjects factor was the date (12 levels). Comparison of parameters between treatments was conducted using the Bonferroni test. All above analyses were carried out with STATISTICA 10.0 (Statsoft Inc, Tulsa, USA).

Table 1 - Main traits of fire behavior and weather conditions of spring burnings in El Pozuelo and Beteta.

\begin{tabular}{cccccccccc}
\hline Z & PN & T & RH & WS & LHFc & SCHmm & Tmi & Tmo & Tmi $>60$ \\
\hline-- & -- & ${ }^{\circ} \mathrm{C}$ & $\%$ & $\mathrm{~m} / \mathrm{s}$ & $\%$ & $\mathrm{~cm}$ & ${ }^{\circ} \mathrm{C}$ & ${ }^{\circ} \mathrm{C}$ & $\mathrm{s}$ \\
\hline El Pozuelo & P3B & 20.17 & 53.12 & 0.17 & 16.9 & 32 & 32.8 & 139.8 & 24.5 \\
El Pozuelo & P4B & 21.97 & 47.47 & 0.81 & 25.8 & 66 & 61.9 & 312.9 & 17.5 \\
El Pozuelo & P6B & 22.42 & 42.61 & 1.32 & 38.2 & 113 & 54.6 & 175.3 & 41 \\
Beteta & B2B & 18.80 & 34.77 & 0.79 & 22.4 & 151 & 32.2 & 199.3 & 11.5 \\
Beteta & B5B & 20.65 & 33.10 & 0.71 & 18.3 & 150 & 52.4 & 285.0 & 60 \\
Beteta & B6B & 21.69 & 30.15 & 0.82 & 21.4 & 178 & 37.4 & 352.8 & 12.1 \\
\hline
\end{tabular}

Note = Z: zone; PN: plot number; T: temperature air; RH: relative humidity; WS: mean wind speed; LHFc: percentage of fuel load consumed (LHF); SCHmm: mean maximum stem char height; Tmi: mean temperature of inner bark; Tmo: mean temperature of outer bark; tmi>60: mean time that the temperature in inner bark was higher than $60^{\circ} \mathrm{C}$.

\section{Results}

\subsection{Litterfall}

The mean accumulated litterfall collected in control and burned plots in El Pozuelo and Beteta during the first and second year are shown in Table 2.

Table 2 - The mean accumulated litterfall.

\begin{tabular}{cccc}
\hline P & PT & El Pozuelo & Beteta \\
\hline-- & -- & $\mathrm{kg} \mathrm{ha}^{-1}$ & $\mathrm{~kg} \mathrm{ha}^{-1}$ \\
\hline \multirow{2}{*}{ May 2016 - April 2017 } & Control & $\begin{array}{l}3171 \\
(649)\end{array}$ & $\begin{array}{c}2028 \\
(530)\end{array}$ \\
\hline \multirow{2}{*}{ May 2016 - April 2017 } & \multirow{2}{*}{ Burned } & $\begin{array}{l}3257 \\
(598)\end{array}$ & $\begin{array}{c}3520 \\
(135)\end{array}$ \\
\hline \multirow{2}{*}{ May 2017 - April 2018 } & \multirow{2}{*}{ Control } & 3537 & 2585 \\
& & $(583)$ & $(762)$ \\
\hline \multirow{2}{*}{ May 2017 - April 2018 } & \multirow{2}{*}{ Burned } & 2991 & 3120 \\
& & $(191)$ & $(327)$ \\
\hline
\end{tabular}

Note $=$ P: Period of time; PT: Plot treatment .

In El Pozuelo, litterfall peak took place in September during the first year, both in unburned and burned plots (670 kg ha-1 y $525 \mathrm{~kg} \mathrm{ha}^{-1}$ respectively). In the second year the maximum took place in August for both unburned and burned treatments $\left(917 \mathrm{~kg} \mathrm{ha}^{-1}\right.$ and $684 \mathrm{~kg} \mathrm{ha}^{-1}$ respectively). The minimum peak occurred in December of the first year for the two treatments $\left(37 \mathrm{~kg} \mathrm{ha}^{-1}\right.$ y $28 \mathrm{~kg} \mathrm{ha}^{-1}$ 
in unburned and burned plots). In the second year, the minimum took place in January and February for unburned and burned plots ( $84 \mathrm{~kg} \mathrm{ha}^{-1}$ and $82 \mathrm{~kg} \mathrm{ha}^{-1}$ respectively).

In Beteta, during the first year, litterfall peak took place in August in untreated plots $\left(420 \mathrm{~kg} \mathrm{ha}^{-1}\right)$ and in August-September in treated plots (574-577 $\left.\mathrm{kg} \mathrm{ha}^{-1}\right)$. The same situation in August was repeated during the second year (785 kg ha-1 in untreated plots and $632 \mathrm{~kg} \mathrm{ha}^{-1}$ in treated). Minimum amount of biomass collected occurred during December in the first year for both treatments $\left(55 \mathrm{~kg} \mathrm{ha}^{-1}\right.$ and 31 $\mathrm{kg} \mathrm{ha}^{-1}$ in unburned and burned plots) and in February for both treatments in the second year ( $81 \mathrm{~kg}$ $\mathrm{ha}^{-1}$ and $55 \mathrm{~kg} \mathrm{ha}^{-1}$ in unburned and burned plots respectively).

In El Pozuelo, in control plots, $47 \%$ and $45 \%$ of annual litterfall, respectively for the first and second year, were collected during the summer (July, August and September). A similar percentage took place during that period, in burned plots, collecting $45 \%$ the first year and 52\% the second one. But, litterfall came early in the second year (amount of litterfall was collected in June), reaching percentages of $60 \%$ and 57\% in control and burning plots respectively, from June to August.

A similar situation occurred in Beteta. In control plots during the summer, it was produced $51 \%$ of annual litterfall the first year and $38 \%$ the second year. Similar percentages were obtained in burned plots: $45 \%$ the first year and $40 \%$ the second year. As well, the second year, the level of litterfall collected in June was representative, reaching percentages of 48 and $45 \%$ in control and uncontrol plots respectively.

In control plots from El Pozuelo, needles represented $41 \%$ and $42 \%$ of annual litterfall during the first and second year respectively. Similar percentage appeared in burned plots during the first and second year (51\% and $49 \%)$.

In control plots from Beteta, needless represented 59\% and 39\% of annual litterfall during the first and second year respectively. In burned plots this percentage was 55\% and 35\% in the first and second year.

In El Pozuelo, inflorescences showed the same pattern during the first and second year (Fig. 1). The amount of inflorescences in burned plot decreased regarding to unburned plots especially during the months of maximum litterfall in this fraction (May, June and July). In fact, $46 \%$ less inflorescences were trapped in burned plots during the first year. This percentage was slightly less during the second year $(45 \%)$. After the months of maximum litterfall, the differences between burned and unburned plots were barely noticeable. This same pattern was repeated in Beteta during the two years for which data are currently available ( $42 \%$ less inflorescences in burned plots during the first year and $18 \%$ less in the second year).
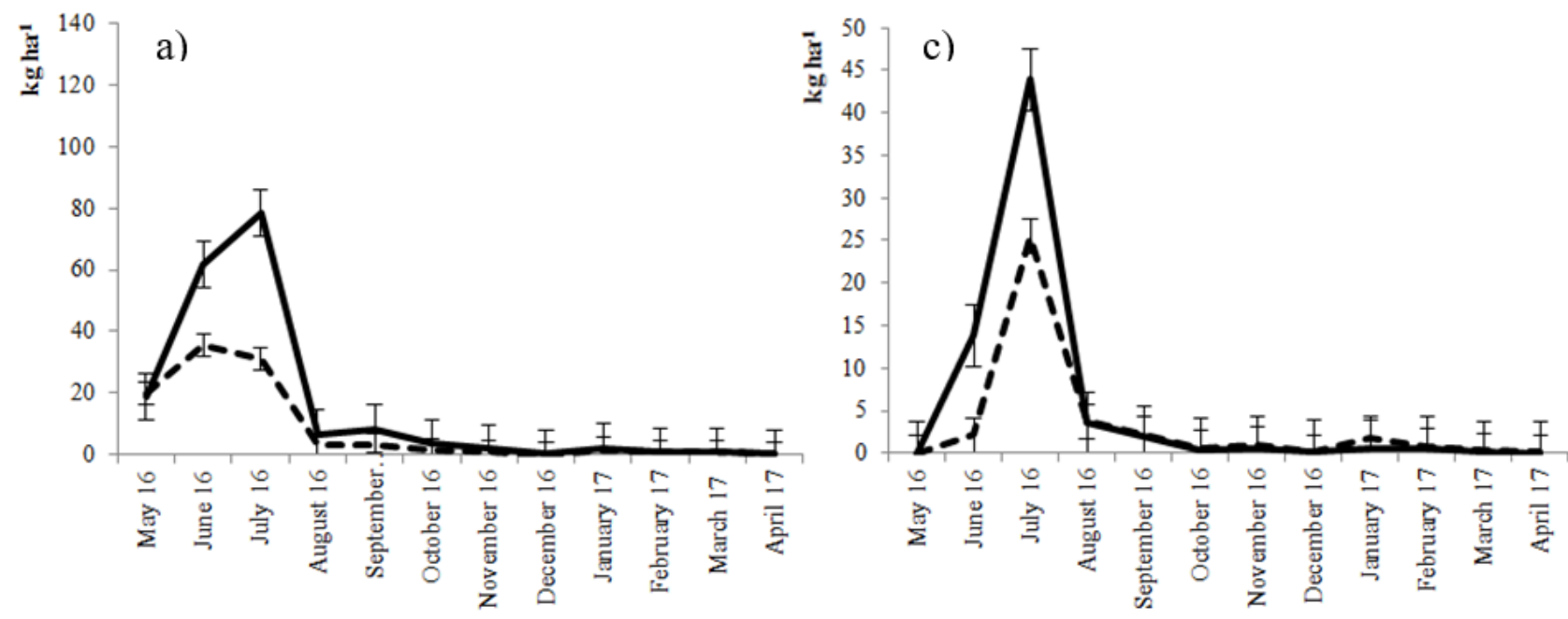

Advances in Forest Fire Research 2018 - Page 396 

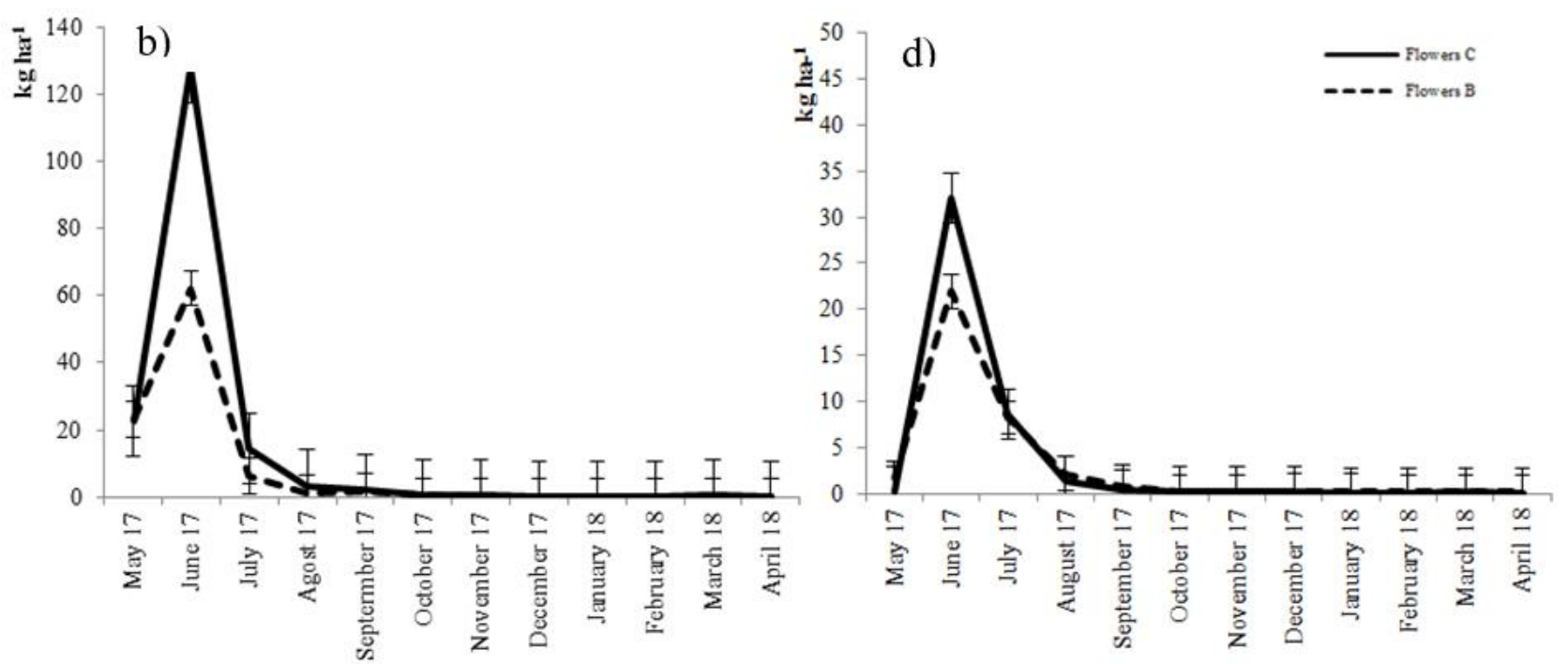

Figure 1 - Inflorescences $\left(\mathrm{kg} \mathrm{ha} \mathrm{h}^{-1}\right)$ collected in El Pozuelo during $1^{\text {st }}$ year (a), in El Pozuelo during $2^{\text {nd }}$ year (b) in Beteta $1^{\text {st }}$ year $(c)$ and in Beteta 2 nd year $(d)$. Control in solid line and burned in dashed line. Control plots $(n=3)$, burned (n=3). Bars show standard errors. Significant differences (ANOVA repeated measurements, Bonferroni test p<0,05) are detected in June-July (El Pozuelo) and June (Beteta) for 1st and 2nd year after burning.

\section{Discussion}

Litterfall is one of the main components of net primary production (NPP) (Hansen et al., 2009) and along with root recycling, more than half of the nutrients absorbed by all are represented (Binkley, 1986). Our findings suggest that prescribed burning might change the patterns and regimes of litterfall biomass, at least in the short time (Espinosa et al., 2017). In fact, although the amount of total litterfall in burning plots of El Pozuelo was not significant regarding control plots (only $\approx 3 \%$ more litterfall in burning plots) an increase in needles in the two months after prescribed burning was observed. Beteta there was a short-term effect of prescribed burning in the amount of total litterfall with an increase of $\approx 74 \%$ in burning plots regarding control plots. The increasing of total biomass (especially the amount of needles) may be an important effect determining the longevity (time since last burning) of prescribed burning, especially in more productive ecosystems. Thus, the short term impact of treatment and the recovery of fuel and structure may result decisive to evaluate the effectiveness of prescribed burnings (Mirra et al., 2017).

During the second year, in maximum litterfall season (June-August) in El Pozuelo it was observed that the mean litterfall is higher in control plots than in burned plots. In Beteta, although the mean litterfall in burned plots was still higher than in control plots, the differences have been reduced and the effect of fire has been weakened. This may be due to the immediate effect of fire that dampen over the years and it is expected that the amount of biomass collected will be stabilized to ordinary values in subsequent years. Although there is scarce information in Europe assessing the effect of fire on litterfall biomass, there are some studies that evaluate the effect of silvicultural treatments, such as thinning, with similar results (e.g. Roig et al., 2005, Blanco et al., 2006). The differences in the findings obtained between El Pozuelo and Beteta might be because of differences in pure and mixed stand structure. Natural disturbances, including fires, disrupt ecosystem structure or function for time periods longer than the current seasonal vegetation cycle (Jactel et al., 2009). Mixed stand might contribute to maintain the stability of ecosystems and biogeochemical cycles. In fact, there is consensus that a minimum number of species is essential for ecosystem functioning under constant conditions (Loreau et al., 2001). In the second year, the total amounts of biomass collected increased with respect to the first year, which may be due to extraordinarily dry summer registered that year in the study area. In some Mediterranean species, the greatest flow of litterfall is gradual due to factors such as the longer 
duration of the light period (which leads to an increase in growth hormones) as well as temperature increases and factors such as water stress. In fact, Pausas et al., (1994) found high intrannual variability in the analysis of litterfall due to climatic variability along a bioclimatic gradient.

One of the effects observed during the first year from May to July (months just after the burns) and in the two zones, was a decrease in the inflorescences in the burned plots regarding the unburned ones (Fig. 1a, 1c). This effect has been maintained in the second year also in the two zones (Fig. 1b, 1d). In Beteta, $42 \%$ less quantity of inflorescences was collected in burned plots than in unburned plots and this percentage was maintained in the second year (46\%). In the case of El Pozuelo during the first year it was $46 \%$ less and in the second year this amount was $45 \%$ less in burned plots. Pinus nigra is a species able to tolerate low surface fires (Fernandes et al., 2008; Fulé et al., 2008). Despite this, its distribution has been reduced dramatically in mountains areas of the Mediterranean region (López Serrano et al., 2009). Spanish black pine is not serotonin, and the persistence of the ecosystem is related to the productions of inflorescences and the later establishment. In fact, many factors are cited hindering the regeneration in Pinus nigra stands (including forest fires), masting, dry summers over consecutive years or excessive grazing (Lucas-Borja et al., 2017). As well, Lucas-Borja et al. (2016) reported that prescribed burning reduces de emergence and increase the mortality of seedlings during the first year as regards control plots. In addition, Pinus nigra presents regular cycles of fructification every 6-8 years which generate discontinuous pulses of natural regeneration. Consequently, burns two years before a pulse of fructification (maturation period of cones) could be critical to guarantee the regeneration in some managed areas. In view of our findings prescribed burnings must be carefully planned in forest management, in particular when are aimed at regeneration in Pinus nigra pure and mixed stands.

\section{Conclusion and management aplications}

Pinus nigra is a non-serotype species, to guarantee the stand survival depends on the production of inflorescences and the success of their implantation. A decrease in the production of inflorescences in burned plots with respect to the unburned plots has been observed during the first and the second year in the two study zones. The litterfall continues being monitored in order to assess the effect of prescribed burning in the medium term (3-4 years) and a complete database of litterfall in pure and mixed stands is being generated. Moreover, the next evaluation of the number of cones two years after burning will ratify or not these results: if the amount of fructification were similar between plots, the fall of inflorescences would not be a good index of fructification potential, probably because prescribed burnings only affect to male flowers sited in the lower parts of the crown. But, if the number of cones were higher in the control plots, we could assume that prescribed burning significantly affects the regeneration potential in Pinus nigra stands. It is well known that prescribed burning is a tool for forest fuel management that can contribute to the reduction of severity of forest fires. But, its inclusion must take into account the peculiarities of each forest ecosystem, evaluating the affections to each part of tree. Litterfall is an important phenological indicator of climate change. Some studies have shown the importance of climate conditions on the litter production. In our work located in Central Spain, an increase in litterfall biomass has been seen after a dry period. Thus a careful planning of prescribed burning must be done under extreme weather conditions.

Scarce information of the impact of fire in foliar and non-foliar biomass is available in Europe and more research is needed to confirm the preliminary results.

\section{Acknowledgments}

This study was supported by the GEPRIF project (Fire Severity Reduction through New Tools and Technologies for Integrated Forest Fire Protection Management), Spanish R\&D project (RTA201400011-C06-01). GEPRIF is co-funded by the EU through the FEDER program. This study was also 
co-financed by INIA (FPI-SGIT 2015) and European Social Fund through a grant awarded to Juncal Espinosa. We thank Cristina Carrillo, Carmen Díez and Ángeles Tirado from INIA-CIFOR for the assistance during the experiment; Fire Extinguishing Service in Cuenca (SEIF Cuenca) responsible for the execution and conduct of prescribed fires and ICP Forests organization and their countries collaborators for the litterfall data base.

\section{Conflicts of Interest}

The authors declare no conflict of interest.

\section{References}

Agee, J.K., Skinner, C.N., 2005. Basic principles of forest fuel reduction treatments. Forest ecology and management, 211(1-2), 83-96. doi:10.1016/j.foreco.2005.01.034.

Alía, R., Martín, S., De Miguel, J., Galera, R., Agúndez D., Gordo, J., Salvador, L., Catalán G., Gil, L., 1996. Las regiones de procedencia de Pinus pinaster, Organismo Autónomo de Parques Nacionales y ETSI de Montes, Madrid.

Allué, J.L., 1990. Atlas Fitoclimático de España. Taxonomías. Ministerio de Agricultura, Pesca y Alimentación. Instituto Nacional de Investigaciones Agrarias, Madrid.

Arkle, R.S., Pilliod, D.S., Welty, J.L., 2012. Pattern and process of prescribed fires influence effectiveness at reducing wildfire severity in dry coniferous forests. Forest Ecology and Management, 276, 174-184. doi:10.1016/j.foreco.2012.04.002.

Binkley, D., 1986. Forest nutrition management. John Wiley \& Sons.

Blanco, J., Imbert, J., Castillo, F., 2006. Influence of site characteristics and thinning intensity on litterfall production in two Pinus sylvestris L. forests in the western Pyrenees. Forest Ecology and Management, 237(1-3), pp.342-352. https://doi.org/10.1016/j.foreco.2006.09.057.

Christopoulou, A., Fulé, P., Andriopoulos, P., Sarris, D., Arianoutsou, M., 2013. Dendrochronologybased fire history of Pinus nigra forests in Mount Taygetos, Southern Greece. Forest Ecology and Management, 293, pp.132-139. https://doi.org/10.1016/j.foreco.2012.12.048.

Cochrane, M.A., Moran, C.J., Wimberly, M.C., Baer, A.D., Finney, M.A., Beckendorf, K.L., ... Zhu, Z., 2012. Estimation of wildfire size and risk changes due to fuels treatments. International Journal of Wildland Fire, 21(4), 357-367. doi:10.1071/WF11079.

Espelta, J.M., Retana, J., Habrouk, A., 2003. An economic and ecological multi-criteria evaluation of reforestation methods to recover burned Pinus nigra forests in NE Spain. Forest Ecology and Management, 180(1), 185-198. https://doi.org/10.1016/S0378-1127(02)00599-6.

Espinosa, J., Madrigal, J., De La Cruz, A.C., Guijarro, M., Jimenez, E., Hernando, C., 2018. Shortterm effects of prescribed burning on litterfall biomass in mixed stands of Pinus nigra and Pinus pinaster and pure stands of Pinus nigra in the Cuenca Mountains (Central-Eastern Spain). Science of The Total Environment, 618, 941-951.

Felton, A., Lindbladh, M., Brunet, J., Fritz, Ö., 2010. Replacing coniferous monocultures with mixedspecies production stands: an assessment of the potential benefits for forest biodiversity in northern Europe. Forest ecology and management, 260(6), 939-947.

Fernandes, P.M., Botelho, H.S., 2003. A review of prescribed burning effectiveness in fire hazard reduction. International Journal of wildland fire, 12(2), 117-128. https://doi.org/10.1071/WF02042.

Agee, J.K., and Skinner, C.N. 2005. Basic principles of forest fuel reduction treatments. Forest ecology and management, 211(1-2), 83-96. doi:10.1016/j.foreco.2005.01.034.

Fernandes, P., Vega, J., Jiménez, E., Rigolot, E., 2008. Fire resistance of European pines. Forest Ecology and Management, 256(3), pp.246-255. https://doi.org/10.1016/j.foreco.2008.04.032. 
Finney, M.A., McHugh, C.W., Grenfell, I.C., 2005. Stand-and landscape-level effects of prescribed burning on two Arizona wildfires. Canadian Journal of Forest Research, 35(7), 1714-1722. doi:10.1139/x05-090.

Flannigan, M.D., Krawchuk, M.A., de Groot, W.J., Wotton, B.M., Gowman, L.M., 2009. Implications of changing climate for global wildland fire. International journal of wildland fire, 18(5), 483-507.

Fulé, P.Z., Ribas, M., Gutiérrez, E., Vallejo, R., Kaye, M.W., 2008. Forest structure and fire history in an old Pinus nigra forest, eastern Spain. Forest Ecology and Management, 255(3-4), 1234-1242.

Graham, R.T., McCaffrey, S., Jain, T.B., 2004. Science basis for changing forest structure to modify wildfire behavior and severity. The Bark Beetles, Fuels, and Fire Bibliography, 167. doi:10.2737/RMRS-GTR-120.

Hansen, K., Vesterdal, L., Schmidt, I.K., Gundersen, P., Sevel, L., Bastrup-Birk, A., ... Bille-Hansen, J., 2009. Litterfall and nutrient return in five tree species in a common garden experiment. Forest Ecology and Management, 257(10), 2133-2144.

Jactel, H., Nicoll, B.C., Branco, M., González-Olabarría, J.R., Grodzki, W., Långström, B., Moreira, F., et al., 2009. The influences of forest stand management on biotic and abiotic risks of damage. Ann. For. Sci. 66 (7), 701.

López-Serrano, F.R., Rubio Caballero, E., Andrés Abellán, M., Del Cerro Barja, A., García Morote, F.A., De las Heras Ibañez, J., Lucas-Borja, M.E., Moya Navarro, D., Odi Lara, M., 2009. Efectos del Cambio climático en los bosques castellanomanchegos. In: Rodríguez Torres, A., Fernández Castro, H., Rojano Saura, I. (Eds.), Impactos del Cambio climático en Castilla La Mancha. Fundación General de Medio Ambiente, Castilla-La Mancha, Spain.

Loreau, M., 2001. Biodiversity and ecosystem functioning: current knowledge and future challenges. Science 294 (5543):804-808. https://doi.org/10.1126/science.1064088.

Lucas-Borja, M., Madrigal, J., Candel-Pérez, D., Jiménez, E., Moya, D., Heras, J., Guijarro, M., Vega, J., Fernández, C., Hernando, C., 2016. Effects of prescribed burning, vegetation treatment and seed predation on natural regeneration of Spanish black pine (Pinus nigra Arn. ssp. salzmannii) in pure and mixed forest stands. For. Ecol. Manag. 378: 24-30.

Lucas-Borja, M., Candel-Pérez, D., Onkelinx, T., Fule, P., Moya, D., Gómez, R., De las Heras, J., 2017. Early Mediterranean pine recruitment in burned and unburned Pinus nigra Arn. ssp. salzmannii stands of central Spain: Influence of species identity, provenances and post-dispersal predation. Forest Ecology and Management, 390, pp.203-211. https://doi.org/10.1016/j.foreco.2017.01.026.

Mirra, I.M., Oliveira, T.M., Barros, A.M., and Fernandes, P.M., 2017. Fuel dynamics following fire hazard reduction treatments in blue gum (Eucalyptus globulus) plantations in Portugal. Forest ecology and management, 398, 185-195. https://doi.org/10.1016/j.foreco.2017.05.016.

Ordóñez, J., Retana, J., Espelta, J., 2005. Effects of tree size, crown damage, and tree location on postfire survival and cone production of Pinus nigra trees. Forest Ecology and Management, 206(1-3), pp.109-117. https://doi.org/10.1016/j.foreco.2004.10.067.

Pausas, J.G., Carceller, F., Vallejo, V.R., 1994. El desfronde en bosques de Pinus sylvestris L. en relación con las características climáticas. Ecología, (8), 167-176.

Pausas, J.G., 2015. Bark thickness and fire regime. Funct. Ecol. 29, 315-327. https://doi.org/10.1111/1365-2435.12372.

Roig, S., del Río, M., Cañellas, I., Montero, G., 2005. Litter fall in Mediterranean Pinus pinaster Ait. stands under different thinning regimes. Forest Ecology and Management, 206(1-3), pp.179-190. https://doi.org/10.1016/j.foreco.2004.10.068. 
Schütz, J., Götz, M., Schmid, W., Mandallaz, D., 2006. Vulnerability of spruce (Picea abies) and beech (Fagus sylvatica) forest stands to storms and consequences for silviculture. European Journal of Forest Research, 125(3), pp.291-302. https://doi.org/10.1007/s10342-006-0111-0.

Touchan, R., Baisan, C., Mitsopoulos, I., Dimitrakopoulos, A., 2012. Fire History in European Black Pine (Pinus nigra Arn.) Forests of the Valia Kalda, Pindus Mountains, Greece.Tree-Ring Research, 68(1), pp.45-50. https://doi.org/10.3959/2011-12.1.

Ukonmaanaho, L., Pitman R, Bastrup-Birk A., Breda N, Rautio P., 2016: Part XIII: Sampling and Analysis of Litterfall. In: UNECE ICP Forests Programme Co-ordinating Centre (ed.): Manual on methods and criteria for harmonized sampling, assessment, monitoring and analysis of the effects of air pollution on forests. Thünen Institute for Forests Ecosystems, Eberswalde, Germany, 15 p.

Wimberly, M.C., Cochrane, M.A., Baer, A.D., Pabst, K. 2009., Assessing fuel treatment effectiveness using satellite imagery and spatial statistics. Ecological Applications, 19(6), 1377-1384. https://doi.org/10.1890/08-1685.1. 